\title{
Basic Reversed-Phase Liquid Chromatography
}

National Cancer Institute

\section{Source}

National Cancer Institute. Basic Reversed-Phase Liquid Chromatography. NCI Thesaurus.

Code C161771.

A form of reversed-phase liquid chromatography where the mobile phase has a $\mathrm{pH}$ greater than 7. 